\title{
Characteristic Features of Medieval Geopolitical Considerations: An Analysis of 12th-Century Hungarian-German Diplomatic Relations
}

\author{
Máté Kavecsánszki \\ MTA-DE Ethnology Research Group, Hungary
}

Copyright $(2016$ by authors, all rights reserved. Authors agree that this article remains permanently open access under the terms of the Creative Commons Attribution License 4.0 international License.

\begin{abstract}
The objective of this research project is to present a significant time period in the system of diplomatic relations between the Kingdom of Hungary and the Holy Roman Empire in the 12th century. My intention has been to focus on the effects of the rule of the Hohenstaufen dynasty on Hungarian foreign policy. I have examined this issue as embedded in a broad international system of relations, including Hungarian-Polish, Hungarian-Czech, German-Polish, German-Czech, and German-Hungarian connections. I have also investigated the Hungarian foreign policy relevance of the conflict between the Hohenstaufen and Welf dynasties. My purpose through this is to call the attention of experts in this field of study to the less often highlighted peculiarities of medieval diplomatic and geopolitical thinking. Beside a chronological presentation of the events in the diplomatic system of contacts, I regularly refer to the differences between Hungarian and German historiography, as regards the interpretations of the sources quoted. Through utilizing the most recent and not so recent findings in Hungarian and German historical research, the reinterpretation of the sources might be used for the proper handling of these anomalies, for finding a consensus between the oftentimes entirely contradictory viewpoints in historical scholarship and, consequently, for providing a more precise description of the events occurring in the diplomacy of the given historical time period.
\end{abstract}

Keywords Kingdom of Hungary, Holy Roman Empire, Austria, Geopolitics, The Middle Ages

\section{Introduction}

The conquest of the Carpathian Basin by the Hungarian people in the 9th century and the foundation of their Christian state therein at the dawn of the 11 th century constitute a fairly familiar chapter within the history of Europe. The circumstances of the conversion of Hungarians to the Christian faith, the ensuing change of lifestyle, the settlement in the Carpathian Basin, the adoption of West European political, economic, and social patterns, and the establishment of contacts with the neighboring states (such as the Holy Roman Empire, the Byzantine Empire, and Poland) are all periods of Hungarian history which have been thoroughly investigated and explored even by historians in Europe (see, e.g. Berend, Urbanczyk, Wiszewski 2013 [3]; Jaritz, Szende 2016 [14]; Kristó 1992 [16 p128-133]; Kristó 1993 [18]; Kristó 1996 [19]; Kristó 2002 [20 p39-47]; Szabó 2012 [33 p9-21]; Zsoldos 2001 [38]). This is much less true about the events of diplomatic history in the 12 th century. This is the time period when the consolidating Hungarian state really became part and parcel of and a significant factor in, Central European political life. The objective of my research is to expand the range of information available about the system of relations between the Kingdom of Hungary and the Holy Roman Empire in the 12th century, together with a critical examination of the sources of this information. In my study, I offer a brief analysis of the effects of the rule of the Hohenstaufen dynasty in the Holy Roman Empire on Hungarian foreign policy, highlighting how the Hungarian state became a decisive actor on the stage of European diplomatic life.

\section{Materials and Methods}

During the course of my research, priority has been granted to the examination of the situation, possibilities, and actual role of foreign policy for the Hungarian state in the 12 th century beside the exploration of events of purely diplomatic historical significance. Thus, in addition to the analysis of German-Hungarian relations, the highlighting of pan-European parallels as well as the issue of the position of Hungary on the international political scene in Europe is also given special emphasis. Apart from the works of Hungarian historians, there are also studies written by German historiographers used for my investigations. As a rather 
significant portion of the medieval historical sources in Hungary were destroyed due to the devastation by the Turks in the 16th and 17th centuries, the relevant sources and archival documents available in Germany today also had to be used during the research process. Thus, I repeatedly refer to and quote from several sources, less frequently cited in Hungary, including the volumes of Monumenta Germaniae Historica as well as Annales Erfesfurtenses, Herbordi Dialogus, Royal Chronicles of Cologne, Historia Welforum Weingartensium, and Reinhardsbrunner, Admonter, and Salzburger Briefsammlungs. Beside a chronological presentation of the events in the diplomatic system of contacts, I regularly discuss the differences between Hungarian and German historiography as regards the interpretations of the sources quoted. Through utilizing the most recent and not so recent findings in Hungarian and German historical research, the reinterpretation of the sources might be used for handling these anomalies, for finding a consensus between the oftentimes entirely contradictory viewpoints in historical scholarship and, consequently, for providing a more precise description of the events occurring in the diplomacy of the given historical time period. This seems to be the most necessary in the historical evaluation of the Byzantine-German rivalry and cooperation concerning (threatening?). Hungary in the 12th century as well as about the relevance and calling into question of the world-dominating orientation of German foreign policy under Conrad III and Frederick I (Barbarossa).

\section{Discussion}

\subsection{Béla II, King of Hungary, and the Hohenstaufen Takeover in the Holy Roman Empire}

The beginning of the reign of Béla II (1131-1141) was characterized by the struggle against Boris, the bastard son of the former king, Kálmán (1095-1116). The most important consequence of this was that the Polish king, Boleslaw III, became an ardent supporter of the pretender to the throne, providing the basis through this for the breaking out of the Polish-Hungarian war. The Hungarian-Polish relations had been hostile since 1126, and Boleslaw hoped that, in the event of Boris' success, he would be able to forge an anti-German coalition with the Kingdom of Hungary (Kristó - Makk 1988 [22 p175]; Makk 1986 [25 p110]; Varga 2003 [34 p174]). An alliance between the Kingdom of Poland and the medieval Hungarian state that covered the entire area of the Carpathian Basin would have really caused serious problems for the Holy Roman Empire. The support provided for Boris by the Polish also took the form of active but unsuccessful military aid (Dümmerth 2003 [7 p188-189]). Due partly to the Polish conflict, and partly to the mediation of the Bohemian duke who got into a familial relationship with the House of Árpád, there was a successful diplomatic contact established between Hungary and Holy Roman
Emperor Lothar (the Saxon) III. (Ann. Saxo a. 1135. [2 p769]; Ann. Erpfhesfurdenses a. 1135. [1 p540]; Ottonis Chronicon [30 p336.k.8.note]). Certain sources prove that, in 1134, a delegation under the leadership of Péter, the Hungarian Bishop of Veszprém, visited the emperor (Pauler 1899 [31 p244]; Deér 1928 [6 p117]. In turn, Lothar defeated Boleszlaw the following year, and the latter had to do penance on August 15, 1135 in Merseburg, in front of the victorious Lothar (Ann. Saxo a. 1135. [2 p769]; Makk 1986 [25 p112]. It was also at the meeting in Merseburg that the envoys of Pope Innocent II, Byzantine Emperor John II Komnenos, and the Doge of Venice met Lothar and tried to persuade him to join the military campaign planned against Roger II, King of Sicily (Ann. Erpfhesfurdenses a. 1135. [1 p540]. The Hungarian delegates had stayed in Germany since July, and they had also participated in the previous imperial assembly held in Magdeburg (Ottonis Chronicon [30 p336 k. 8. note]). Lothar accepted the position of campaign leader, and the Hungarian representatives then announced that Hungary would also join the united forces (Ann. Erpfhesfurdenses a. 1135. [1 p540]. The fact of actual joining can only be considered probable on the basis of contemporary sources, the same way as the consensus in Hungarian historiography about the assumption that the Hungarian and the German rulers indeed formed an alliance (Varga 2003 [34 p177]).

The establishment of the anti-Norman coalition was largely dependent on the German interior political situation, i.e., on the opposition between Lothar III, of Saxon descent, and the Hohenstaufen dynasty. The King of Hungary resolutely took the side of Lothar (and Pope Innocent II, at the same time), not acknowledging the validity of the power of Conrad III of the House of Hohenstaufen, who had been elected anti-king in 1127. This could be due to the fact that Lothar's position in the 1130-as started to gradually become stronger as opposed to that of the Hohenstaufens (Varga 2003 [34 p175]), and Hungary apparently did not wish to take risks. Beside this, it was also obvious that one of the most important reasons for joining the Greek-German-Venetian coalition was to ensure Hungarian rule in Dalmatia, launched by the Hungarian king Kálmán at the beginning of the 12th century (Deér 1928 [6 p119]; see also Kristó 2003 [21 p165-166]; Ann. Erpfhesfurdenses a. 1135. [1 p 540]), as the Dalmatian conquests of Hungary definitely threatened the interests of both Venice and the Byzantine Empire.

Thus, Béla II managed to develop a fairly stable relationship with the Holy Roman Empire, and the act of joining the international coalition provided such a solid foundation for the traditional friendly relations with Germany, so characteristic of this dynasty, that even the ascent of Lothar's enemy, the Hohenstaufen dynasty, to power could not affect it (the conclusion being that the Hungarian ruler had not been anti-Hohenstaufen before either, for which reason his partner in alliance was not identified as any of the dynasties but as the German empire itself) (Cf. Varga 2003 [34 p178-179]). It is very important 
though that the party looking for amity in this relationship at that time was not Hungary any longer (Deér 1928 [6 p120]).

Following the death of Lothar III in 1137, the duke with the largest landed property in the Empire was the Welf duke Henry the Proud. Beside the Bavarian Duchy, he also owned Saxony through his wife and, in addition, he possessed Tuscany, too. He could have had a good chance of getting elected German king, except, just like way back in 1125, the other German dukes did not wish to put someone into a ruler's position above them with such a huge size of family holdings. For similar reasons (mainly because of the possession of Tuscany), the Welf duke was not supported by Pope Innocent II either. Accordingly, the dukes decided to legitimize in 1138 the rule of the Hohenstaufen anti-king, Conrad III. (Görich 2008 [10 p29]; see also Kurze 1894 [24 p103-104]; Fuhrmann 1983 [9 p142]; Bockmann 1987 [4 p69-71]). As a consequence of the Hohenstaufen accession to the throne then, the Hohenstaufen-Welf interior war was resumed in the Holy Roman Empire.

From the aspect of Hungarian-German relations, the important part of this development was that the Bavarian Duchy across the border from Hungary was in the hands of the arch enemies of the new dynasty. Thus, the German king elect could be legitimately concerned about a potential Welf-Hungarian alliance (Deér 1928 [6 p120]; Varga 2003 [34 p175-178]), as such instances of cooperation had been traditional in the second half of the 11th century between Hungary and the German pretender to the throne. As a result, Conrad III tried to do his best to make sure Hungary was on his side in order to thwart the implementation of a potential cooperation between the Hungarian state and the heads of the Welf territorial complex bordering Hungary. An example of his efforts was the betrothal of his four-year-old son, Henry, to Béla's even younger daughter, Sophia, in 1139, followed by Sophia's relocation to Germany (Kristó, Makk 1988 [22 p181]). Conrad III also used measures of internal political nature to restrict the power and authority of the Welfs. Reaching back to the ancient traditions of the empire, he announced that no duke was allowed to own and control simultaneously more than one tribal duchy, for which reason he called upon Henry the Proud to waive his right of ownership of either Bavaria or Saxony (Görich 2008 [10 p31]; Kurze 1894 [24 p104]; Fuhrmann 1983 [9 p133-143]; Bockmann [4 p71]). As the latter refused to comply with this instruction, Conrad decided to deprive him of both and then gave Bavaria to his half-brother, Leopold IV of Babenberg (Görich 2008 [10 p31]; Kurze 1894 [24 p104]).

The untimely death of Duke Henry on October 20, 1139, resulted in a radical change in Hungarian-German relations. As we already know, the Welf Duke had already lost Bavaria the previous year anyways, but his death eventually determined the question of the Duchy for good. Although the Welf resistance did not come to an end in Saxony, the fate of Princess Sophia was doomed, as the possibility of a Hungarian-Welf coalition with the dropout of Bavaria as an independent duchy was rather faint. What is more, King Béla also died on February 13, 1141.

\subsection{Diplomatic Relations between Géza II and the Hohenstaufen Rulers up until the End of the 1150s}

In 1141, the throne of the Kingdom of Hungary was ascended by Géza II (1141-1162) of the House of Árpád, who was only 11 years old at that time. During the first half of the $1140 \mathrm{~s}$, the Hungarian-German relations deteriorated parallel with the strengthening of the power of the Hohenstaufens. The position of Conrad III continued to improve gradually as of the ascension of Géza II to the throne. The first stage of this process was when the Babenbergs came into power in Bavaria. By 1142, the Hohenstaufens-Welf conflict had become more or less balanced, which resulted in a compromise. Conrad III returned Saxony to Henry the Lion (the son of Henry the Proud, who had died in 1139), as a consequence of which the Welfs gave up their claim to the ownership of Bavaria in favor of the Babenbergs. Leopold IV died in 1141, and was followed on the throne by his brother, Henry (Jasomirgott) Babenberg. He, in turn, married the widow of Henry the Proud, called Gertrude, who was the mother of the Saxon Duke Henry the Lion (Bockmann 1987 [4 p59]; Görich 2008 $\left.\left[\begin{array}{ll}10 & \mathrm{p} 32\end{array}\right]\right)$. The Babenbergs had been related to the Hohenstaufens even before, but the dynastic connection between the Hohenstaufens and the Welfs was crowned by Gertrude through this marriage. Naturally, all this made it virtually impossible for Hungary to interfere in the internal affairs of the empire (Deér 1928 [6 p122]). At the same time, it also meant that there was no acceptable justification any longer for maintaining the engagement between Duke Henry and Sophia, which had been initiated back in 1139. The rude termination of the diplomatic relations could be best illustrated by the extraordinary and insulting case of the decision that there would be no marriage between Duke Henry and the daughter of the Hungarian king, Sophia. According to the sources consulted, the daughter of the Hungarian king was treated in the German court in such an unacceptable fashion that, around 1145 - or, perhaps, at the beginning of 1146 (Zimmermann 2005 [36 p133]) - she split up with her betrothed husband-to-be and became a nun at the convent of Admont (Kristó, Makk 1996 [23 p177-178]; Herbordi Dialogus I. [11 p35-40]. Beside the temporary interim period in the Hohenstaufen-Welf conflict, the breaking up of the engagement might have also been prompted by the hopes of Conrad for a potential marriage of his son to a wife from Byzantium (Cf. Fuhrmann 1983 [9 p144]; Varga 2003 [34 p182]). Establishing a familial relationship with the Byzantine emperors might have seemed more advantageous for the German imperial dynasty than building similar ties with the Hungarian royal family.

In addition to the case above, the deterioration of Hungarian-German relations was also indicated by the interference of the German side into Hungarian internal affairs. In order to implement his hegemonistic plans in Europe, Conrad III had pursued a more and more aggressive 
course in foreign policy since the middle of the 1140 s, for which he needed a partnership with the states around the borders of his empire (Varga 2003 [34 p130]). However, King Géza II was not exactly in a position to afford such a partnership and the accompanying unconditional conformity (Makk 1986 [25 p120], as he was intent on strengthening the leading role of the Kingdom of Hungary in Central Europe. For this token, the German king tried to intervene in the Hungarian rivalry for the throne in an indirect fashion (by supporting the claim of Boris to the Hungarian throne, which has been mentioned above and, if successful, could have resulted in making the pretender a vassal king dependent on his German lord and ruler) (Varga 2003 [34 p173]). It is a fact that Boris indeed got into contact with the German king (Ottonis Chronicon VII [30 p365-366]), who, upon the recommendation of the Czech duke and Henry (Jasomirgott) of Babenberg gave him permission to recruit mercenaries on Bavarian-Austrian territories and to launch an attack against the Hungarian king (Kristó, Makk 1996 [23 p176]). Boris did manage to take the fort of Pozsony (present-day Bratislava) in Western Hungary for a short time in 1146 (Otto von Freising 1913 [8 p105-106]). In principle, this was supposed to be a private initiative on the part of the Austrian-Bavarian mercenaries and their employer. In practice, however, it would be difficult even to imagine that Duke Henry, a staunch supporter of the Hohenstaufens, could have broken the peace without the knowledge and consent of King Conrad - even if we are ready to question the actual existence of a German-Hungarian alliance operating from 1134 onwards (Varga 2003 [34 p175]). Upon arrival, the Hungarian army, headed by the king, forced Boris to find and accept a consensus (Ottonis Gesta I. 31. [29 p48]). According to the not completely consistent report issued by Bishop Otto of Freising, who was in the service of the Bavarian duke and was also of Babenberg descent on his father's side, following the re-conquest of Pozsony, Géza declared war on the "duke of Noricum" and led a huge army against him (Ottonis Gesta I. 31. [29 p48]). This meant that the Hungarian army entered the territory of Bavaria, i.e., the territory of the Holy Roman Empire (Pauler 1899 [31 p261]). In addition, Géza II immediately contacted the inner opposition of Conrad III, and issued monetary aid to Welf VI, the Bavarian duke who had been driven away beforehand, in order to assist the latter in taking his lands back. (As Gertrude died in 1143, her son, Henry the Lion issued a claim for Bavaria on the basis of maternal heritage. As a consequence of this step, the war between the Hohenstaufens and the Welfs broke out again) (Makk 1986 [25 p121]; Historia Welforum [12 p468]). Thus, in September 1146, 70 thousand Hungarian troops, led by Géza II, invaded the province of Henry Jasomirgott, as chronicled by Bishop Otto of Freising (Ottonis Gesta I. 31. [29]; Kristó 1986 [15 p $80-81])$. The operation that took place between the rivers Lajta and Fischa was basically a military response to the attack of almost six months before. On September 11th, the Hungarian army defeated the Germans to an extent that left a long-lasting impression in the memory of the latter (Varga
2003 [34 p182]). The fact that a counter-attack was not initiated by Conrad III was probably due to the coincidental arrival of the news to Europe on the fall of Edessa, which meant that the German king also had to take part in the second crusade (Hóman, Szekfü 1935 [13 p369]). Géza was concerned about any potential military conflict, in order to avoid which he made sure that the troops of the empire could march through Hungary on their way to the Holy Land with relative peace and quiet in June-July of 1147 (Deogilo [27 p61]; Zimmermann 2005 [36 p128]).

The events described above may be considered to have been consecutive and logical consequences of differing viewpoints and conflicts working at the regional level; however, they were also closely connected to a higher-level, almost continental, sequence of events, which embedded them in a much deeper context.

The actual story had begun way back in 1143 when, following the death of Gertrude of Supplingenburg, her son Henry the Lion announced his claim on Bavaria of the Babenbergs, through which act the war between the Hohenstaufens and the Welfs was resumed. At this point, Conrad III decided to reaffirm his connection with Byzantium, the ruler of which, Emperor Manuel I, he was in a familial relationship (Ostrogorsky 2003 [28 p332]; Bockmann 1987 [4 p75]). Incidentally, the mother of Manuel was Piroska of the House of Árpád, which meant that the Emperor of Byzantium was also the grandson of (Saint) László I of Hungary. Henry Jasomirgott, upon returning from the Holy Land, brought along the Byzantine princess Theodora Komnena for his wife. As a result, it was not only the Hohenstaufens who were in close relationship with the Byzantine dynasty, but also Hohenstaufen-related Babenbergs as well. Thus, the Bavarian dynasty had very serious political connections which, on the one hand, could help them in their efforts of making Austria an independent political unit (and, as a consequence, separate from Bavaria) (Bockmann 1987 [4 p78]), while on the other hand, they could also be part and parcel of the strategy which intended to force Hungary into an uneasy position between the Holy Roman Empire and Byzantium (Zöllner 1998 [37 p57]). For the Emperor of Byzantium, the German connection (1148) (Görich 2008 [10 p35-36]) came in handy, because he had increasingly serious conflicts with the Norman Kingdom of Southern Italy (Makk $1986 \quad\left[\begin{array}{ll}25 & \text { p124-127 }\end{array}\right]$. The establishment of this coalition, however, prompted movement in all the circles of European diplomacy. Byzantium was supported by the Holy Roman Empire, Venice, and the Principalities of Susdal and Halich, while the Normans sided up with the German duke Welf VI, the French king Louis VII, the Pope, the Serbian Grand Zupan, the Russian dukes of Volhynia and Kiev, and the Hungarian king Géza II (Kristó 1993 [17 p164]; Deér 1928 [6 p123]; Makk 1986 [25 p126]). We know for a fact that King Géza sent an envoy at the head of a delegation to Roger II of Sicily during the course of 1149, on the basis of which Hungary's access to the French-Norman coalition can be concluded between 1149 and 1154 (Zimmermann 2005 [36 p129-130]; 
Varga 2003 [34 p185]). The Byzantine-German alliance could mean a rather dangerous situation for Hungary this time, too (Deér 1928 [6 p124]), which was promptly recognized by Géza II, and which also determined the foreign policy orientation of Hungary for the years after 1146 (or, perhaps, even from as early as 1145).

The development of the Hungarian-Byzantine war fitted the operational mechanism of the alliance system presented above, as the Hungarian attacks against our southern neighbor, Byzantium, made it impossible for the Byzantine emperor to focus on raiding the Normans in Southern Italy (Ostrogorsky 2003 [28 p332-333]). Along the other channel of this coalition policy, Géza II supported Duke Welf IV by issuing financial aid to him as of the summer of 1146 to the beginning of the $1150 \mathrm{~s}$ in order to help him access the Bavarian throne. Through the financial support provided for maintaining the German internal conflict, the Hungarian king tried to prevent a potential German campaign against Hungary in response to the 1146 events (i.e., the battle at the River Fischa) (Kristó, Makk 1996 [23 p184]). This political effort proved to be successful, as the armed revolts of both Duke Welf IV and of his nephew, Henry the Lion, made it impossible for Conrad III to carry out any raid between 1149 and 1151 against Hungary (or against the Normans, for that matter) (Varga 2003 [34 p185]).

Basically, from the 1150s onwards, King Géza's efforts to attract the German dukes and provincial lords to take his side or at least take a neutral position in the conflict were pretty much obvious, and he managed to do his best in this respect to obstruct their participation in a potential empirical expansion conducted at the expense of Hungary among others. The same must have been the purpose of the negotiations started in 1151 either by high-ranking envoys (or Géza II, himself) with Duke Henry of Bavaria (Deér 1928 [6 p127]; Makk 1986 [25 p137]). Reconciliation seemed to be an essential precondition for the establishment of peaceful relations with the western neighbors, and this also proves that Géza II must have obtained fairly accurate information concerning the interior affairs of the empire. A proof of this could be that the Hungarian king switched sides from Welf IV to Henry Jasomirgott exactly when the former gave up his resistance after his defeat at the beginning of 1150 and tried to come to terms with Conrad III through the mediation of Frederick, who was still the Duke of Swabia at that time (Varga 2003 [34 p186]).

However, when negotiations commenced about electing Frederick to become German king following the death of Conrad III (in 1152) (Váczy 1936 [35 p549]), it was quite obvious that, in the case of a successful election, Frederick would definitely consider the territorial claim of the Welfs for Bavaria acceptable. It needs to be noted that both Conrad III and Welf VI were the uncles of Frederick, which means that the Welf and the Hohenstaufen dynasties were in fact united in his person (Görich 2008 [10 p38-39]; Rexroth 2008 [32 p69]). Yet, if the Welfs should get Bavaria back at this point in time, it would mean that the Babenbergs would be slighted to some extent (Varga 2003 [34 p186]).
Thus, Hungarian-German relations essentially became strained and fragile as of 1152, with Frederick I (Barbarossa) ascending the throne, which was even more aggravated by the fact that the ancestry of the new king substantially brought about the reconciliation of the Hohenstaufen and the Welf camps. In addition, Frederick was even more inclined towards an anti-Hungarian policy in the east than his uncle had been before, which also had a favorable effect on the Central European plans of the Byzantine emperor, Manuel, too (Deér 1928 [6 p127]). As early as June 1152, Frederick proposed a plan in Regensburg for attacking and subduing Hungary (Freising 1913 [8 p160]; Varga 2003 [34 p187]). However, his plan was not accepted by the German dukes and princes, who offered their own problems in internal affairs as an excuse for rejecting it (Kristó, Makk 1996 [23 p187]; Ottonis Gesta II. [29 p107]). Beside this latter argument, it may also be assumed that the diplomatic efforts of Géza II did indeed work after all (Deér 1928 [6 p127]). Among the major German dukes and princes, it was not only the Welfs who did not support the idea of attacking Hungary, but there was also some rapprochement starting between Géza II and Henry Jasomirgott due to the negotiations held in the previous year. This was made even more evident and palpable by the fact that the Babenbergs did not support Frederick's election, as it represented a risk for their rule in Bavaria (Varga 2003 [34 p186]). It is in the light of this that we should judge and evaluate the rejection of Barbarossa's plan put forward at the imperial diet. The explanation is that, as long as the conflict about Bavaria, i.e., the Welf-Babenberg rivalry was not settled, the military campaign against Hungary could not be implemented, for the simple reason that an essentially important basis and deployment preparatory area for that would be the region of Bavaria.

As a result of the above, it seems quite clear that a turn was required in the inimical relationship between Frederick and Géza II, which Frederick did indeed take at last. In addition, it should also be noted that, apart from the resistance of the dukes and princes, the international political situation was also less than favorable for conducting a military campaign against Hungary at that point in time, since Frederick also wished to fight against Sicily in an alliance with the Byzantine Emperor, following the path that Conrad III had set up for him (Varga 2003 [34 p189]), although the Byzantine-German alliance (1149) did not prove to be long lasting either. As a result of the dissolution of the alliance between the two emperors, the danger of their joint action against Hungary was also gone and, although the Greek war was carried on for some time, it became essentially insignificant on the stage of world politics (Bockmann 1984 [4 p74]; Varga 2003 [34 p187]).

Despite the fact that Frederick continued to keep the plan for attacking Hungary on the agenda, there was still no pretext in his hands that would have provided substantial legal basis for it. What is more, the issue of Bavaria still remained a problem to be solved. It seems obvious that, in order to stabilize the position of the empire, and not 
necessarily for the purpose of launching a military campaign against Hungary, it was crucial for him to settle this matter for good.

As it has been mentioned above, Conrad III awarded Bavaria to the Babenberg family. Barbarossa was related to the Hohenstaufens on his father's side and to the Welfs on his mother's side (Görich 2008 [10 p36]; Váczy 1936 [35 p549]), which meant that, upon his ascendance to the throne, the key to reconciliation between the two dynasties was represented by Bavaria. For this reason, Frederick I returned this duchy to the Welfs (in 1155) instead of granting it to the Babenbergs' Henry (Jasomirgott). For the same token, the Babenbergs had to be compensated with "another" duchy (Görich 2008 [10 p39-40]; Rexroth 2008 [32 p69]). It seems to have been a notable consideration that, by conferring this "donation" to the Welfs, Frederick also intended to establish peaceful circumstances in interior affairs for his projected Italian enterprise. However, in consequence of this step taken by Frederick, Henry the Lion thus became the owner of two principalities again (Bockmann 1987 [4 p82]). So, in order to compensate the Babenbergs, Frederick granted the title of duchy to Austria in 1156, the territory of which he actually "tore" out of Bavaria (Bockmann 1987 [4 p83]; Kurze 1894 [24 p108]), with the special privilege that made it possible to inherit it even by female members of the family and, if there should be no heir apparent, it was the duke's prerogative to appoint his successor.

Nevertheless, the shift in the status of Austria could have had an anti-Hungarian twist to it as well. Frederick gave it to his uncle on condition the latter would support him against the neighboring states (Const. I. [5 p222]; Makk 1986 [25 p149]; Bockmann 1987 [4 p86-87]; Görich 2008 [10 p40]; Zöllner 1998 [37 p57]). However, since the document called Privilegium minus mentions the neighboring states only in general, i.e., without specifically naming Hungary, the anti-Hungarian aspect of it is questioned in most recent German historiography, while the significance of the deed is emphasized as part of the process the result of which was the relocation of the questions related to the Hungarian issue into the jurisdiction of the principalities (i.e., under the authority of the Czech, Austrian, Bavarian, and Styrian dukes) (Varga 2003 [34 p192]). Nevertheless, a very important detail must not be overlooked in this case. I have already mentioned above that Conrad III was still very much concerned about a potential Hungarian-Bavarian (Welf) alliance, partly because of the geopolitical position of Bavaria. This concern might have played a part in giving Bavaria to the Babenbergs. When Frederick I decided to grant Bavaria to the Welfs again, and did not take Saxony back from them, the same situation could have occurred anew. I believe that, in the strategy of elevating Austria to an independent duchy, the effort of breaking the Hungarian-Bavarian geopolitical unity could also have been a consideration, as there was a new, unconditionally pro-Hohenstaufens duchy wedged between the two territories. In addition, the fact that the Babenbergs ceased to be the vassals of the Bavarian duke after the establishment of the independent Austrian duchy also needs to be noted here (Görich 2008 [10 p40]; Bockmann 1987 [4 p84]). At the same time, the transformation of Austria into a duchy was part and parcel of the new "eastern policy" that was first attempted to be implemented by Frederick Barbarossa. The essence of this was that he intended to grant a more significant role to the local factors, i.e., the local powers, in the eastern policy of the empire (Deér 1928 [6 p128]). The plan did not work out exactly as Frederick had intended it to. The new local factors; namely, Austria in this case, turned out to dispose of enough power to pursue independent diplomatic policies that occasionally were in opposition to that of the emperor.

\section{Results}

In my work, I have made an attempt at describing and analyzing the structure of German-Hungarian diplomatic contacts between 1131 and 1156 , which seems to be a time period when a definite, pioneering, and internationally active and successful Hungarian foreign policy was established. Although there are still a lot of questions left unanswered concerning several events in this time interval, there is still a clearly discernible direction in Hungarian-German contacts that can be identified:

It was roughly in the middle of the reign of Béla II (1131-1141), a member of the Árpád Dynasty, that the diplomatic system of relations was formed the consequences of which I have monitored in my study up until the year 1156 . The direct point of departure for this was the Hungarian-Polish relationship, which had been hostile since 1126 and also burdened with a war later on (Dümmerth 2003 [7 p188-189]; Kristó, Makk 1988 [22 p115-116]; Makk 1986 [25 p110]), only to be appeased through foreign policy successes in other directions by the Hungarian king (Makk 1986 [25 p110-111]; Varga 2003 [34]). The Austrian military aid was due to the earlier successful diplomacy of Béla II, as a result of which he entered into an alliance with Leopold III, Margrave of Austria and through the mediation of Sobeslav I, Duke of Bohemia, who was married to Adelaide of Hungary, he also ensured the support of Holy Roman Emperor Lothar III in 1134 (Ann. Erfesfurdenses 1135 [1 p540]; Ann. Saxo 1135 [2 p769]; Makk 1986 [25 p115-116]; Varga 2003 [34 p175]). This contact meant the immersion of Hungarian foreign policy into German interior policy conflicts (Lothar III against the Hohenstaufens).

King Béla II sided up with Lothar III (who was emperor as of 1133) exactly when the situation of the latter got clearly stable in Germany against the Hohenstaufens (Ann Erphesfurdenses 1135 [1 p540]; Deér 1928 [6 p119]; Kristó 2003 [21 p165-166]; Varga 2003 [34 p178-179]). Although the most recent German historical findings do not unanimously acknowledge the existence of the alliance mentioned above (Varga 2003 [34 p177]), its possibility cannot be denied as an antecedent to joining the anti-Norman coalition of 1135 . This latter event provided the dynasty's traditional German partiality with such a solid basis that even 
the ascent to power by the Hohenstaufen dynasty, the enemies of Lothar, could not change it (Varga 2003 [34 p178-179]). It is very important though that the party looking for amity at that time was not Hungary any more (Deér 1928 [6 p120]). In 1138, the imperial dukes legitimized the power of Conrad III, the (former) anti-king in opposition to Henry (the Proud) of the House of Welf, the most powerful duke of the Holy Roman Empire with the largest size of landed property, as a result of which the Hohenstaufen-Welf conflict was resumed (Bockmann 1987 [4 p69-71]; Fuhrmann 1983 [9 p142]; Görich 2008 [10 p29]; Kurze 1894 [24 p103-104]). The Bavarian Duchy neighboring Hungary was in the hands of the enemies of the new dynasty, so the newly elected German king could be legitimately concerned about a potential Welf-Hungarian alliance. For this reason, Conrad III tried to move and keep Hungary on his side as efficiently as possible out of pure strategic considerations: through the betrothal and engagement of Henry, the heir to the throne, and Sophia of Hungary, the first daughter of Béla II. (Kristó, Makk 1988 [22 p181])

However, the untimely death of Duke Henry on October 20,1139, resulted in a radical change in Hungarian-German relations. The Welf duke had already lost Bavaria the previous year anyways (as Conrad had given it to the Babenbergs), but his death eventually determined the question of the Duchy for good, in addition to deciding the fate of Princess Sophia, too, since the possibility of a Hungarian-Welf coalition with the dropout of Bavaria as an independent duchy was rather faint (Deér 1928 [6 p122]; Herbordi Dialogus [11 p35-40]; Zimmermann 2005 [36 p133]).

Thus, with the internal political crisis no longer threatening, Conrad terminated the engagement between the royal infants in 1145 or at the beginning of 1146 on the one hand, while on the other hand he made Hungary the target of more and more aggressive German foreign political attacks (Varga 2003[34 p130]). For this token, he first supported the rival candidate for the Hungarian throne (Boris Kalamanos) against the king, and then, in 1146, it was probably possible through his consent that an attack against Pozsony (present-day Bratislava) was launched (Makk 1986 [25 p120]; Varga 2003 [34 p173]). The 1146 counter-attack in response to this by Hungary, identified as the battle along the river Fischa, - seems outstanding from the perspective of demonstrating the military and political power of the Hungarian state in addition to its significance in military history (Ottonis Chronicon [30 p48]; Mayböck 2009 [26 p6]; Pauler [31 p261]).

It seems necessary to evaluate the rather strained (practically, bellicose) nature of the Hungarian-German relations also in the context of Hungarian-Byzantine and German-Byzantine connections. The reason for this is that the relationship between the two emperors had an extraordinary significance for the political existence of Hungary, wedged between the two empires (Zöllner 1998 [37 p57]). According to the view shared by most representatives of Hungarian historical science, the hazard inherent in a potential German-Byzantine alliance constituted the backbone of the history of Hungarian-German diplomatic relations in the 12th century from this point onwards (Deér 1928 [6 p124]). The 1148, (partially) anti-Norman, German-Byzantine coalition, from the perspective of the 1146 events, automatically swung Hungary (in 1149) to the side against the Germans, ie., into the camp of the Normans, the French, and the Welfs (Bockmann 1987 [4 p77]; Deér 1928 [6 p123]; Kristó 1993 [17 p164]; Makk 1986 [25 p124-127]; Varga 2003 [34 p185]; Zimmermann 2005 [36 p129-130]).

Hungarian foreign relations, which became more and more active as of 1148, were dominated and determined by an anti-German orientation. The Hungarian-German relations became especially critical in 1152, when Frederick Barbarossa ascended the throne, as he hastened to announce his plans of attacking Hungary right after his ascension (Ottonis Chronicon [30 p107]; Makk 1986 [25 p137]; Varga 2003 [34 p186]). The fact that this attack was canceled might be due to the efforts of Hungarian foreign policy apart from the German interior conflicts, as the objective of the latter was to win over the German heads of individual provinces without contacting the head of the empire (Deér 1928 [6 p127]; Varga 2003 [34 p186]). Furthermore, another favorable turn of events for Hungary was the termination of the alliance between the two emperors in 1151 (Bockmann 1987 [4 p74]; Deér 1928 [6 p128]; Varga 2003 [34 p187]). Among the measures taken by Frederick I Barbarossa against Hungary, the transformation of Austria from an imperial fief into a hereditary sovereign duchy in 1156 needs to be noted, as its partial objective was the minimization of the possibility of a future Hungarian-Bavarian coalition (Bockmann 1987 [4 p82-83]; Deér 1928 [6 p128]; Görich 2008 [10 p36]; Kurze 1894 [24 p108]; Rexroth 2008 [32 p 69]; Zöllner 1998 [37 p57]).

\section{Summary}

In this paper, I have intended to give a brief overview and analysis of the effects of the Hohenstaufen dynasty's access to power on Hungarian foreign policy, providing proof of the fact that geopolitical thinking was also a decisive factor in shaping the diplomatic processes of the Middle Ages. In the focus of the diplomatic system of relations in Central Europe, which started to develop as of the 1130s, we can identify the interaction between the efforts of the Holy Roman Empire for European hegemony and the attempts of the Kingdom of Hungary to pursue a more and more independent and determined at times almost imperialistic, foreign policy. This interaction is made even more complex by the interior conflict between the Hohenstaufen and Welf dynasties in the Holy Roman Empire and by the either friendly or hostile relationship between the two European empires (i.e., the Holy Roman state and Byzantium). I have provided substantial proof and evidence even in this short paper to support the assumption that, in medieval foreign political 
thinking and strategy, the consideration of geopolitical aspects was of outstanding importance, despite the fact that the specific term itself did not even exist at that time. The situation of the Kingdom of Hungary, geographically located between the two imperial powers (covering a fairly large area, including the whole of the Carpathian Basin), was fundamentally determined by the current, and oftentimes changing, relationship of the two empires. At the same time, the question of rule and authority over Bavaria, the duchy adjacent to the Kingdom of Hungary, was equally important to any of the Holy Roman emperors for basically similar reasons. There can be no doubt about the fact that a potential Hungarian-Bavarian (Welf) alliance, which would have represented a serious threat to any Holy Roman ruler, must have played a part in inserting Austria, elevated to the status of a duchy, between the Hungarian and Bavarian borderlines.

\section{Acknowledgements}

I would wish to express my sincere gratitude to Dr. Attila Bárány, Professor at the Institute of History of the University of Debrecen (Hungary). All I know about diplomacy in the Middle Ages comes from what I have learned from him. the research has been aided by the MTA-DE Ethnology Research Group.

\section{REFERENCES}

[1] Annales Erphesfurdenses anno 1125-1137. Monumenta Germaniae Historica. Scriptores. 6. Edente D. G. Waitz, Prof. P. Kilan. 536-541.

[2] Annalista Saxo anno 741-1139. Monumenta Germaniae Historica. Scriptores. 6. Edente D. G. Waitz, Prof. P. Kilan. $547-777$.

[3] N. Berend, P. Urbanczyk, P. Wiszewski. Central Europa in the High Middle Ages. Bohemia, Hungary and Poland c. 900 - c. 1330. Cambridge University Press, Cambridge, 2013.

[4] H. Boockmann. Stauferzeit und spätes Mittelalter. Deutschland 1125-1517, Siedler Verlag, Berlin, 1987.

[5] Constitutiones et acta publica imperatorum et regum. I. Monumenta Germaniae Historica. Legum. Sectio IV. Tomus I.

[6] J. Deér. A magyar törzsszövetség és a patrimoniális királyság külpolitikája [The Foreign Policy of the Hungarian Alliance of Tribes and Patrimonial Kingdom], Kaposvár, 1928.

[7] D. Dümmerth. Az Árpádok nyomában [In the Footsteps of the Árpáds], Corvina Press, Budapest, 2003.

[8] O. v. Freising: I. Frigyes császár tettei [Achievements of Emperor Frederick I], Budapest, 1913.

[9] H. Fuhrmann. Deutsche Geschichte im Mittelalter von der Mitte des 11. bis zum Ende des 12. Jahrhunderts. Deutsche Geschichte 2., Kleine Vandenhoeck-Reihe, Göttingen, 1983.
[10] K. Görich. Die Staufer. Herrscher und Reich, Verlag C.H. Beck, München, 2008.

[11] Herbordi Dialogus de vita Ottonis episcopi Babenbergensis. Monumenta Germaniae Historica. Scriptores 33. Edidit Georgius Henricus Pertz.

[12] Historia Welforum Weingartensium anno. 800-1167. Monumenta Grmaniae Historica. Scriptores. 21. Editore Ludewico Weiland. 1859. 454-471.

[13] B. Hóman, Gy. Szekfü. Magyar történet I. [Hungarian History I.], Budapest, 1935.

[14] G. Jaritz, K. Szende (ed.). Medieval East Central Europe in a Comparative Perspective. From frontier zones to and in focus. London, New York, 2016.

[15] Gy. Kristó. Az Árpád-kor háborúi [Wars in the Árpád Era], Zrínyi Katonai Press, Budapest, 1986.

[16] Gy. Kristó: Directions of Orientation in the Carpathian Basin at the End of the First Millennium. In: Mutual Dynamics of

[17] Organisational Levels in Evolution. Ed. Béla Lukács. Budapest, 1992. 128-133.

[18] Gy. Kristó. A Kárpát-medence. A magyarság régmúltja (1301-ig) [The Carpathian Basin: The Ancient Past of Hungarians], Szeged, 1993.

[19] Gy. Kristó. Die Arpadendynastie. Die Geschichte Ungarns von 895 bis 1301. Budapest, 1993.

[20] Gy. Kristó. Hungarian History in the ninth Century. Szeged, 1996.

[21] Gy. Kristó. Die ungarische Staatsgründung. In: Die ungarische Staatsbildung und Ostmitteleuropa. Hrsg. Von Ferenc Glatz. Begegnungen. Schiftenreiche des Europa Institutes Budapest. Band 15. Budapest, 2002. 39-47.

[22] Gy. Kristó. Magyarország története 895-1301 [A History of Hungary], Osiris Press, Budapest, 2003.

[23] Gy. Kristó, F. Makk. Az Árpád-házi uralkodók [Rulers from the House of Árpád], Budapest, 1988.

[24] Gy. Kristó, F. Makk. Az Árpád-ház uralkodói. [Rulers of the House of Árpád], Budapest, 1996.

[25] F. Kurze. Deutsche Geschichte im Mittelalter bis 1500. Sammlung Göschen. 33., Stuttgart, 1894.

[26] F. Makk. Magyarország a 12. században [Hungary in the 12th Century], Gondolat Press, Budapest, 1986.

[27] L. Mayböck. Beitrag zur Besiedlungsgeschichte des Unteren Mühlviertels, Online available from 2006http://www.ooeges chichte.at/uploads/tx_iafbibliografiedb/Mayboeck_Dietmar von_Aist_01.pdf. [2009. 06. 20.]

[28] Odo de Deogilo. De profectione Ludovici VII. regis Francorum in Orientem. Monumenta Germaniae Historica. Scriptores. 26. 59-73. 1882.

[29] G. Ostrogorsky. A bizánci állam története [A History of the Byzantine State], Osiris Press, Budapest, 2003.

[30] Ottonis Gesta Friderici I. imperatoris lib. I. Ottonis et Rahewini Gesta. Monumenta Germaniae Historica. Scriptores. 46. Edente Georg Waitz. Hannover 1912. 1-161. 
[31] Ottonis episcopi Frisigensis Chronicon sive Historia de duabus civitatibus. Monumenta Germaniae Historica Scriptores. 45. Edente Adolfus Hofmeister. Hannover, 1912.

[32] Gy. Pauler. A magyar nemzet története az Árpádházi királyok alatt. I. [The History of the Hungarian Nation under the Rule of the House of Árpád. I.], Budapest, 1899.

[33] F. Rexroth, Frank. Deutsche Geschichte im Mittelalter, Verlag C. H. Beck, München, 2008.

[34] C. Szabó. The Magyar Raids: Fact and Fable. Journal of Eurasian Studies. Volume IV, Issue 4. 2012. 9-21.

[35] G. Varga. Ungarn und das Reich vom 10. bis zum 13 Jahrhundert. Das Herrscherhaus der Árpáden zwischen Anlehnung und Emanzipation. Studia Hungarica. Schriften des Ungarischen Instituts München. Herausgegeben von
Zsolt K. Lengyel, Ralf Thomas Göllner, Horst Glassl. 49., Verlag Ungarisches Institut, München, 2003.

[36] P. Váczy. A középkor története. Egyetemes történet II [A History of the middle Ages: Universal History II.], Budapest, 1936.

[37] H. Zimmermann. A német-magyar kapcsolatok a 12. század közepén és az erdélyi szászok betelepítése [German-Hungarian Relations in the Mid-12th Century and the Settlement of the Saxons from Transylvania], Aetas, Vol. 20, No.4, 124-136, 2005.

[38] E. Zöllner. Ausztria története [A History of Austria], Osiris Press, Budapest, 1998.

[39] Zsoldos, Attila (Ed.). Saint Stephen and his Country. A Newborn Kingdom in Central Europe: Hungary. Essays on Saint Stephen and His Age. Budapest, 2001. 